\title{
Richness, Fatness, and Salvation: The Movement of the Holy Spirit in the Blessings of the Holy Oils and Consecration of the Chrism during the Chrism Mass
}

\author{
SIOBHAN BENITEZ \\ Saint Mary's Seminary and University
}

\begin{abstract}
During the Chrism Mass of Holy Thursday, when the oils of the sick and of the catechumens are blessed and the chrism is consecrated, the whole church assembles to celebrate these symbols of the human journey to God. That the oils and balsam used in the rite are derived from creation signifies the role of creation (specifically nonhuman creatures) in salvation. Indeed, the holy oils, fashioned from creation and blessed and consecrated before the whole church, are destined to mark and enable the journey of human beings toward union with God through the church. The consecration of the chrism is considered the foundation of all other blessings in the church, making it an appropriate lens to consider the relationship among creation, the church, and salvation. These prayers of blessing and consecration during the Chrism Mass indicate the movement of the Holy Spirit in creation, drawing human beings into heaven.
\end{abstract}

Keywords: Chrism Mass, holy oils, nonhuman creation, soteriology, pneumatology

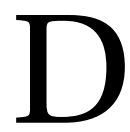
URING the Chrism Mass of Holy Thursday, when the oil of the sick and the oil of the catechumens are blessed and the chrism is consecrated, the whole church assembles to celebrate these symbols of the human journey to God. That the oils and balsam used in the rite are derived from creation-olive trees and natural scents-signifies the role of creation (specifically nonhuman creatures) in salvation. Indeed, the holy oils, fashioned from creation and blessed and consecrated before the whole church, are destined to mark and enable the communal journey of human beings toward

Siobhan Benitez teaches at Saint Mary's Seminary and University in Baltimore. Her research specializes in theological environmental ethics and the intersection of liturgical/sacramental theology and moral theology. She is currently working on a book that outlines the theological and ecological benefits of eating according to the liturgical year. 
union with God through the church. Two heretical tendencies of our timean individualistic neo-Pelagianism and a subjectivist neo-Gnosticismthreaten contemporary understandings of salvation as a communal and embodied undertaking reliant on the salvation brought to us by the Incarnate God and mediated through the church. The consecration of the chrism is considered the foundation of all other blessings in the church, making it an appropriate lens to consider the relationship among creation, the church, and salvation.

As olive berries must be picked and cleaned before they can be made into oil, part I of this paper describes two troublingly heretical tendencies in the contemporary world identified by the Congregation for the Doctrine of Faith in the letter Placuit Deo, a neo-Pelagianism and a neo-Gnosticism, and recommends the Chrism Mass as providing a contextualizing response to those heretical tendencies. Part I also briefly describes previous scholarship on the Chrism Mass. Part II "mills" and "presses" the current rite of the Chrism Mass, outlining significant motifs and emphasizing the communal and embodied nature of the celebration. Oil is not an end in itself, but something to be used, so part III examines the movement of the Holy Spirit in elements of creation in the prayers of blessing of the holy oils and consecration of the Chrism in the current Chrism Mass. These prayers of blessing and consecration indicate the movement of the Holy Spirit in creation-in all creation-to draw human beings into heaven.

\section{Harvest: the Trees and the Preparation}

Olive berries, bitter in their natural state, are harvested and cleaned.

\section{Two Heresies about Salvation}

A recent letter from the Congregation for the Doctrine of the Faith (CDF) addressed to the bishops of the Catholic Church argues that the contemporary world harbors two heretical tendencies in the human understanding of salvation. The first is "A new form of Pelagianism ... one in which the individual, understood to be radically autonomous, presumes to save oneself, without recognizing that, at the deepest level of being, he or she derives from God and from others." ${ }^{1}$ The second tendency is "a new form of Gnosticism [which] puts forward a model of salvation that is merely

${ }^{1}$ Congregation for the Doctrine of the Faith (CDF), Letter to the Bishops of the Catholic Church on Certain Aspects of Christian Salvation (Placuit Deo), February 22, 2018, §3, http://www.vatican.va/roman_curia/congregations/cfaith/documents/rc_con_cfaith_doc_ 20180222_placuit-deo_en.html. 
interior, closed off in its own subjectivism." ${ }^{2}$ This new Gnosticism, like the ancient heresy:

presumes to liberate the human person from the body and from the material universe, in which traces of the provident hand of the Creator are no longer found, but only a reality deprived of meaning, foreign to the fundamental identity of the person, and easily manipulated by the interests of man. ${ }^{3}$

These heretical tendencies boil down to an individualism intent on selfrealization divorced from reliance on God and neighbor or a privileging of personal interiority in pursuit of "the absolute freedom of the human spirit" from external limits like the body and concrete relationships to other people and creatures. ${ }^{4}$ The two are related; in attempting to free oneself from dependency on grace and community, one is tempted to prize one's innermost being as somehow separate from the material relations that sustain the bodily self.

Placuit Deo recommends countering these heretical cultural tendencies with a renewed understanding of salvation through the church, particularly through sacramental participation. The seven sacraments of the church are communal celebrations that underscore the dependency of each human individual on others and on God; the use of material elements in the sacraments recalls that "divine salvation takes on the creaturely order shared by all humanity."5

In this article, I suggest that the movement of the Holy Spirit through the blessing of the holy oils and the consecration of the chrism at the Chrism Mass can be traced both to recognize the dignity and salvific quality of the material world, exemplified in the richness and fatness of olive oil, and to highlight the derivative reality of all human life (i.e., that each human person "derives from God and from others"). ${ }^{6}$ Celebrated in a gathering of the entire local church-bishop, priests from around the diocese, and laity-the Chrism Mass is an appropriate liturgy to consider as respondent to neo-Pelagianism. Celebrated at the close of Lent, in anticipation of Easter, and including the production of the creaturely oils and chrism that

2 Ibid., §3.

3 The CDF readily acknowledges (and so do I) that "the comparison with the Pelagian and Gnostic heresies intends only to recall general common features" and that "there is a great difference between modern, secularized society and the social context of early Christianity, in which these two heresies were born," ibid.

${ }^{4}$ Ibid., $\$ 14$.

5 Ibid., §8.

${ }^{6}$ Ibid., §3. 
will mark and enable the Christian journey toward God, the Chrism Mass is an appropriate liturgy to consider as respondent to neo-Gnosticism as well.

Indeed, the liturgical life of the church always seeks to answer heretical tendencies toward a prideful individualism by emphasizing the communal nature of human life. Not only are individuals dependent upon their biological families for their mere existence, they are also dependent upon wheat and grapes for their daily sustenance. Further, individuals are dependent upon the community of persons who present bread and wine at the altar-the ecclesial community, the body of Christ - that prays to God for assistance with the production of such things as bread and wine. Our salvation is not achieved through personal effort or individual strength, rather, it is constantly offered to all people by a God who wills us to participate "in the new order of relationships begun by Jesus ... by means of the sacraments, of which Baptism is the door, and the Eucharist is the source and summit."7

In answer to recurrent Gnostic tendencies that would deny the goodness of bodily and material reality, the church liturgically emphasizes the embodiedness of the human soul: kneeling in prayer, singing psalms, genuflecting before the Eucharist. The Eucharist itself specifically overcomes the newGnostic attitude that seeks a purely interior salvation, instead providing insight into the significance of creation in the salvation of the whole human person, body and soul. Grapes and wheat gain significance if they will one day communicate the body and blood of Christ to the community assembled for and sustained by Communion.

The ritual use of natural elements to draw the whole human person into God is not limited to bread and wine, but includes water, salt, light, fire, oil, incense, flowers, tree boughs, and ashes. To some, conscious inclusion of natural elements in the liturgy smacks of an undesirable magicalism, but such tension is misplaced. Tasmin Rowe explains, "Rituals for crops, fruits and medicinal herbs in particular were seen to bear a resemblance to spells or 'pagan' practices. ... the Dominican scholar Marie-Dominique Chenu argued that liturgical ritual had absorbed 'certain images and practices borrowed from a religion of nature ... not without degrading effect."'8 Yet there is nothing magical about the use of ashes or oils or water in the liturgy, or

7 Ibid., \$13.

8 Tasmin Rowe, “'Bless, O Lord, This Fruit of the New Trees': Liturgy and Nature in England in the Central Middle Ages," in God's Bounty? The Churches and the Natural World, eds. Peter Clarke, Tony Claydon, and Ecclesiastical History Society, vol. 46, Studies in Church History (Woodbridge, UK: Rochester, NY: Ecclesiastical History Society; Boydell \& Brewer, 2010), 54. Internal quotation from Chenu, "The Symbolist Mentality," in Nature, Man and Society in the Twelfth Century, ed. J. Taylor, trans. L. K. Little (Chicago, IL: University of Toronto Press, 1968), 99-145, at 129. 
asking for God's blessing to come upon crops and herbs; rather, each natural element is recognized sacramentally as intended to facilitate the salvation of human beings. ${ }^{9}$ As Sacrosanctum Concilium maintains, "There is scarcely any proper use of material things which cannot thus be directed toward people's sanctification and the praise of God." ${ }^{10}$

\section{Theological Responses to the Chrism Mass}

Despite its long history, theological reflection on the Chrism Mass has been scant. Detailed attention has been given to the complex history of the liturgy, ${ }^{11}$ but most reflection on the oils themselves has revolved around the rites where they will later be used (e.g., the anointing of the sick, baptism, confirmation, and ordination). Studies speaking of the contemporary Chrism Mass focus on recent changes to the liturgy and rubrics, method of celebration, and the "presbyteral intrusion" upon the liturgy. ${ }^{12}$

9 Rowe, "Bless, O Lord, This Fruit of the New Trees,'” 61; Simon Jones, "Oil," in The Use of Symbols in Worship, ed. Christopher Irvine, Alcuin Liturgy Guides 4 (London: SPCK, 2007), 56.

${ }^{10}$ Second Vatican Council, Constitutions, Decrees, Declarations (Sacrosanctum Concilium), ed. Austin Flannery (Northport, NY: Costello, 2007), \$40.

${ }^{11}$ Those interested in studying the history of the Chrism Mass could consult: John Walton Tyrer, Historical Survey of Holy Week, Its Services and Ceremonials (London: Oxford University Press, 1932); Niels Rasmussen, "The Chrism Mass: Tradition and Renewal," in The Cathedral: A Reader (Washington, DC: US Catholic Conference, 1979), 29-33; Patrick Regan, "The Chrism Mass: Festival of the Priesthood. But Which One?," Worship 86, no. 2 (2012): 124-39; Kevin W. Irwin, Easter: A Guide to the Eucharist and Hours (Collegeville, MN: Liturgical Press, 1991); Anthony Ward, "Sources of the Postconciliar Blessings of the Holy Oils and the Chrism," Ephemerides Liturgicae 125 (2011): 190-233; Annibale Bugnini, The Reform of the Liturgy, 1948-1975, trans. Matthew J. O'Connell (Collegeville, MN: Liturgical Press, 1990).

12 On changes to the liturgy and rubrics, see, for instance, J. Frank Henderson, "Chrism Mass of Holy Thursday," Worship 51, no. 2 (March 1977): 149-58; Ward, "Sources of the Postconciliar Blessings of the Holy Oils and the Chrism." On method of celebration, see Neils Rasmussen and G. Thomas Ryan, "The Chrism Mass: Practical Ideas," in The Cathedral: A Reader (Washington, DC: US Catholic Conference, 1979), 29-33; Gerard S. Sloyan, "Chrism Mass," in New Proclamation Commentary on Feasts: Holy Days and Other Celebrations, eds. William F. Brosend and David B. Lott, New Proclamation (Minneapolis, MN: Fortress Press, 2007), 63-67; Patrick Gorman, "Making a Place for the Whole Assembly: Cathedral Liturgy," Pastoral Music; Washington, DC 36, no. 3 (March 2012): 11-14. On the "presbyteral intrusion" in the new rite, see Regan, "The Chrism Mass: Festival of the Priesthood." Or, from a more positive light, Victoria M. Tufano, "A Kingdom of Priests for God," Pastoral Music; Washington, DC 36, no. 5 (September 2012): 14-16; Kevin C. Rhoades, "Newness in the Chrism Mass," Priest 73, no. 4 (April 2017): 54-54; John J. H. Hammond, "Priest and Triduum," Priest 71, no. 3 (March 2015): 10-13. Matias Augé succinctly comments, "There is no consensus 
The next section of this paper explores some important motifs of the contemporary Chrism Mass.

\section{Production: the Mill and the Press}

Soon after harvest and preparation, the berries are milled into a paste and pressed to release their oil.

\section{Important Motifs in the Chrism Mass}

Before beginning an analysis of the texts of the blessings of the holy oils, I will lay out some general reflections on significant themes current in the Chrism Mass as a whole.

\section{i. Oils}

In the Greco-Roman world, olive oil was used for cooking, as fuel in oil lamps, medicinally rubbed on wounds, and on the skin by athletes before a contest, or scented and rubbed into skin after bathing. ${ }^{13}$ Biblical literature also records a variety of uses for oil. In her little reference work about olives, Fabrizia Lanza writes that in the Old Testament "olives and olive oil signify the fertility and vitality of the promised land, rich in honey and olive trees (Deut 8:8), or sometimes they represent gifts that God gives to his people in reward for their obedience and loyalty." ${ }^{14}$ In the Old Testament, oil is used as a cleansing and healing ointment, to anoint objects, to oil a shield "to make it supple and fit for battle" (Isa 21:5), and to anoint people as "priests, kings and, possibly, prophets" to "confer a new identity upon an individual by consecrating him for a divine purpose and filling him with grace and power to fulfill it." ${ }^{15} \mathrm{~J}$. Roy Porter explains, "one effect of anointing is to create an intimate relationship with God and to bring the recipient into the divine sphere of holiness: thus in Lam 4.20, Yahweh's Anointed is closely approximated to God-as all life derives from the divine breath (Gen 2:7; Ps

among scholars on the meaning and place of this celebration." See Matias Augé, "The Liturgical Year in the Roman Rite," in Liturgical Time and Space, ed. Anscar J. Chupungco (Collegeville, MN: Liturgical Press, 2000), 194. And indeed, some studies of the whole liturgical year, like Martin Connell's otherwise comprehensive Eternity Today, skip over the Chrism Mass and Holy Thursday morning entirely; see Martin Connell, Eternity Today: On the Liturgical Year, vol. 2 (New York: Continuum, 2006).

13 Jones, "Oil," 38.

${ }^{14}$ Fabrizia Lanza, Olive: A Global History (London: Reaktion, 2011), 33.

15 Jones, "Oil," 39. 
104:29-30), so the king is the breath of life to his people." ${ }^{16}$ Jeffrey John summarizes, "the anointing with oil symbolizes the anointing with the Spirit that is simultaneous with it." 17 Anointing with oil concurrently symbolizes and enacts a new relationship with God.

The New Testament's assignation of the title Christ or Messiah (i.e., Anointed One) to Jesus is an obvious continuation of Old Testament anointing imagery. John argues, "Therefore the baptism of Jesus-or more precisely his endowment with the Spirit immediately following the baptism-is understood as his anointing with the Spirit as messianic king, and also as his adoption (in Mark perhaps) or declaration (Matthew and Luke) as God's Son." ${ }^{18}$ Although the word Christ (chrism-anointed one) appears a great many times in the New Testament, the word chrism appears only three times, all in 1 John 2:18-27. Martin Connell's in-depth word study of chrism and antichrist in the New Testament suggests that the church-of the Johannine community at least-regarded anointing with chrism as an initiation rite rather than considering the "anointing" of their members as an entirely symbolic anointing with the Spirit. ${ }^{19}$ Oil's great many natural uses and the biblical association of anointing with the Spirit and with Christ shine through in the liturgy of the Chrism Mass.

\section{ii. Community}

Kevin Irwin argues that "the understanding of this liturgy [the Chrism Mass] as reflecting an important ecclesial event should not be forgotten."20 The Chrism Mass is the only celebration of the liturgical year that gathers the whole local church, bishop, diocesan clergy, religious, and lay faithful, together. ${ }^{21}$ Bishop and priests concelebrate and the whole community

${ }^{16}$ J. Roy Porter, "Oil in the Old Testament," in The Oil of Gladness: Anointing in the Christian Tradition, eds. Martin Dudley and Geoffrey Rowell (London: Collegeville, MN: SPCK; Liturgical Press, 1993), 35.

${ }^{17}$ Jeffrey John, "Anointing in the New Testament," in The Oil of Gladness: Anointing in the Christian Tradition, eds. Martin Dudley and Geoffrey Rowell (London : Collegeville, MN: SPCK ; Liturgical Press, 1993), 6o. Cf. also 1 Sam. 10:1 and Ps. 2.

${ }^{18}$ Ibid., 60.

19 Martin F. Connell, “On 'Chrism' and 'Anti-Christs' in 1 John 2:18-27: A Hypothesis," Worship 83, no. 3 (May 2009): 216. For the opposite thesis, see John, "Anointing in the New Testament."

${ }^{20}$ Irwin, Easter, 16.

${ }^{21}$ Ordinations, which are not a seasonal part of the liturgical year, are also ideally celebrations of the whole local church, though in practice this is often not so. Friends of the men about to be ordained from other dioceses attend as either celebrants or congregants, while the lay faithful of the diocese are, even if welcome, often not formally invited to the ordinations. 
partakes in the Eucharist. Although the bishop presides over the blessing of the oils, the other presbyters extend their hands during the consecration of the chrism. In addition, the whole church is assembled to witness the consecration of the chrism and the blessing of the oils, that is, the whole ecclesia witnesses what the important liturgist Annibale Bugnini describes as "the foundation of all consecrations in the church." ${ }^{22}$ The consecration of the oils, which mark the initiation of new members into the church and, in the case of the oil of the sick, the church's intimate communion with those who feel abandoned, constitutes a liturgical-catechetical moment to which ministers of the holy oils might later refer. Because the whole church gathers to witness the blessing of the oil of the sick, for instance, Niels Rasmussen suggests that he who celebrates the anointing of the sick can ensure that the sick "know that the whole local Church with its bishop has been praying over this oil." ${ }^{23}$ Similarly, the minister of baptism might remind the parents of baptized children that the oil of catechumens, signed upon their children's chests, enacts the exorcism through the strength of Christ's mystical body, the church, which gathered as one to bless the oil at the Chrism Mass. Minutes later at the anointing of chrism upon the children's crowns, they are consecrated priest, prophet, and king, incorporated into the church in all her roles. The bishop, who presided at the Chrism Mass, can particularly draw upon that event as "a source of catechesis for the celebration of the sacraments," when, at a confirmation celebration, he assures the confirmandi "about the prayer of everybody for them" during the Chrism Mass, and perhaps invites them to join in that liturgy the following year. ${ }^{24}$ Rasmussen argues, "The most important rubric in the text of the chrism Mass is that if it is difficult for the clergy and the people to assemble on Holy Thursday morning, the blessing may be held on an earlier day, near Easter, with the celebration of the proper chrism Mass," ${ }^{25}$ prizing the presence of a lot of people who, he maintains, work during the morning and would more likely attend a Chrism Mass held on a week night the week preceding Palm Sunday. The actions of the Chrism Mass are visibly actions of the whole church.

22 Bugnini, The Reform of the Liturgy, 1948-1975, 117.

23 Rasmussen, "The Chrism Mass," 32.

24 Ibid. I do not wish to encourage ad-libbing sacramental liturgies; homilies are meant to include catechesis, and the meaning of the sacramentals used throughout the sacrament at hand offers an excellent source of catechesis.

25 Ibid., 30. 


\section{iii. Bishop}

Sacrosanctum Concilium (SC) 41 reads:

The bishop is to be considered the high priest of his flock from whom the life of his people in Christ is in some way derived and on whom it in some way depends. Therefore, all should hold in the greatest esteem the liturgical life of the diocese centered around the bishop, especially in his cathedral church. They must be convinced that the principal manifestation of the church consists in the full, active participation of all God's holy people in the same liturgical celebrations, especially in the same Eucharist, in one prayer, at one altar, at which the bishop presides, surrounded by his college of priests and by his ministers.

The Chrism Mass, though, is "the only 'seasonal' Eucharistic celebration reserved to the bishop," and the only one, as mentioned previously, that assembles the whole local church, making its celebration the fullest revelation of the bishop's role as the leader of his diocese. ${ }^{26}$

\section{iv. Priesthood}

In 1969, the Congregation for the Clergy issued a circular letter encouraging all priests to renew their dedication to Christ, celibacy, and obedience to their bishop on Holy Thursday. The Congregation for Divine Worship (CDW) was asked to integrate this renewal of priestly promises into texts for the Chrism Mass, and in 1970 the CDW circulated texts for the promises. ${ }^{27}$ Emphasis on the priesthood easily accompanied emphasis on the bishop as outlined in $S C 41$, following "the ritual or quasi-ritual presence of a good part of the diocesan clergy around the bishop in the cathedral church" already assembled for the celebration. ${ }^{28}$

Patrick Regan dubs the regard of the Chrism Mass as a festival of the priesthood a "presbyteral intrusion" on a liturgy whose "primary purpose ... is to bless oils for use especially in the sacraments of initiation at the paschal vigil." ${ }^{29}$ Regan numbers three "presbyteral intrusions" upon the liturgy: (1) concelebration, ${ }^{30}$ (2) renewal of priestly promises after the homily, ${ }^{31}$ and (3) the new preface to the 1970 Chrism Mass, which "recalls the institution of the ministerial priesthood, over and above the royal priesthood of believers,'" 32 confirming Henderson's assertion that "Although it

\footnotetext{
${ }^{26}$ Henderson, "Chrism Mass of Holy Thursday," 149.

27 Bugnini, The Reform of the Liturgy, 1948-1975, 118.

${ }^{28}$ Ibid., 117.

29 Regan, “The Chrism Mass," 132.

3о Ibid., 128.

31 Ibid., 129.

32 The CDW, quoted in Regan, "The Chrism Mass," 130.
} 
might be possible to interpret the wording of this prayer [the collect] as referring to the priesthood of all believers, it seems highly unlikely that this meaning is intended." 33

Despite the recent emphasis on the ordained priesthood, the Chrism Mass also sustains the motif of the priesthood of all believers. The collect ("O God ... grant that, being made sharers in [Christ's] consecration, we may bear witness to your Redemption in the world") ${ }^{34}$ can, as Henderson suggests, be interpreted as referencing all the baptized, a particularly appropriate interpretation given the festal character of the blessing of the oils, two of which are used to anoint the lay faithful. ${ }^{35}$ Indeed, reception of the oil of catechumens is a prerequisite to reception of the chrism, which will anoint the human person as "priest" in the sense of "priesthood of all believers." In addition, the three readings (Isa 61:1-4, 6, 8-9; Rev 1:5-8; and Luke 4:16-22) all refer more readily to the priesthood of all believers than they do to the ordained priesthood. ${ }^{36}$ Whether the Chrism Mass is experientially received as a festival of the priesthood of all believers will depend, in large part, on how well the lay faithful are invited to participate and attend in a given diocese.

\section{v. Soteriological Role}

What has not been discussed in great detail is the soteriological role of the Chrism Mass itself, the primary interest of this study. Historically, the date for the blessing of the holy oils has been variable, being held on Holy Thursday or some time earlier in Lent, but the association with the coming Easter celebration is undeniable. The oils needed to be ready for use in the sacraments of initiation celebrated at the Easter Vigil. ${ }^{37}$ The Chrism Mass, with its significant ecclesial themes and the production of the holy oils, eloquently speaks to soteriology, both of the salvation of those assembled and of those who will one day be anointed by the holy oils.

${ }^{33}$ Henderson, "Chrism Mass of Holy Thursday," 152.

${ }^{34}$ Revised Roman Missal. Thursday of Holy Week. The Chrism Mass, 7.

${ }^{35}$ The oil of the sick anoints Christians who suffer from grave illness, both physical and psychological; the chrism anoints newly baptized babies and candidates during the sacrament of confirmation (Eastern Christians, in fact, call this sacrament chrismation; adults initiated into the Roman Catholic Church will be anointed with chrism just once); the oil of catechumens anoints those who have yet to be baptized and so are not yet formally members of the church.

${ }^{36}$ Cf. Regan, "The Chrism Mass," 128; Ward, "Sources of the Postconciliar Blessings of the Holy Oils and the Chrism," 197.

37 Irwin, Easter, 14-15; Rasmussen, "The Chrism Mass," 30. 


\section{Embodiment and Community Enacted}

Each important motif of the Chrism Mass discussed previously-oils (which clean, heal, feed, and confer relationship), community (which gathers for and utilizes the oils), the bishop (who encounters his whole flock), the priesthood (both ordained and baptismal), and the soteriological role of the Chrism Mass (identifiable through its placement in liturgical time as preparatory for the Easter season)-ritually enacts an embodied and communal soteriology.

The oils represent much that is good in creation: they are medicinal and useful, strengthening and delicious, and they bodily mark those who are anointed as specially related to God. They are also communal, both in their production-many hands are needed to turn an olive grove into olive oiland in their intended use-each of the oils will be used in communal situations and to communicate something about the communal journey of the church to God (see following). The community, the bishop, and the priesthood are all ritually enacted by the presence of their living, breathing selves. The bishop and his community gather together and confirm each other in their roles. The ordained priests renew their vows publicly and aloud while members of the baptismal priesthood confirm their role in the church by standing, kneeling, and praying at the liturgy. The ritual time of the Chrism Mass, the morning of Holy Thursday (for the theological purpose of closing Lent and in anticipation of the new Christian initiates at Easter), or some earlier day (for the theological purpose of ensuring a greater assembly of the community), anticipates and celebrates the soteriological role of the oils: these oils will anoint human beings to and for the community of the church, the community that consciously pursues communion with God. By the ritual use of earthy oils, by the ritual, bodily presence of bishop and priests and laity, by the ritual significance of its placement in liturgical time, the Chrism Mass enacts and embodies the role of creation and community in salvation. ${ }^{38}$

With the general themes "milled" and "pressed" into a rich oil, we now are ready to turn to the purpose of our labor, the benefit of those who will be blessed.

${ }^{38}$ I recall Roy Rappaport's very bodily understanding of what is accomplished and communicated through ritual. The following quotation from his Ritual and Religion in the Making of Humanity captures the notion: "By kneeling or prostrating himself a man seems to be doing more than stating his subordination to an order. He is actually subordinating himself to that order." Roy A. Rappaport, Ritual and Religion in the Making of Humanity (Cambridge: Cambridge University Press, 2010), 142, italics in the original. 


\section{Reception: the Blessing and the Blessed}

After the oil is bottled, it is given to those who will use it; in the case of the church, for blessing and for the blessed.

\section{Blessing of the Oil of the Sick 39}

\section{i. Description of the Oil}

Of the holy oils, it is in the prayer for the blessing of the oil of the sick that the church most clearly calls upon the Holy Spirit, asking God, "Pater ... emitte ... Spiritum tuum Sanctum Paraclitum ... in hanc pinguedinem olei," or, "Father, send your Spirit the Holy Paraclete into this rich oil" (\#20.1-6).40 Modified by the adjective pinguis (rendered "precious" by ICEL in the current translation and "rich" by me), the oil is described in terms of vitality and fertility: it is "fat." That an oil might be fat seems obvious, but the meaning of the term is manifold. The oil being blessed is full-bodied like a good wine, fertile and rich with life like a pregnant woman, precious because of its quality (a "fat" oil comes from the first pressing), fat and strong like well-kept livestock. These approximations of what it means for an oil to be rich all point to the same meaning: we (the church addressing God in the blessing) do not ask that the Holy Spirit come upon petrol or yesterday's used cooking grease; rather, we ask the Holy Spirit to come upon the best oil, that which symbolizes a fertile and vital ground.

${ }^{39}$ References to the prayers of blessing and consecration will be given as in-text citations following the format \#rubric number.line number; e.g., \#20.1 would refer to the Blessing of the Oil of the Sick (\#20), line 1, “Deus, totius ..."; line numbers always refer to the delineation in Pontificale Romanum ex Decreto Sacrosancti Oecumenici Concilii Vaticani II Instauratum Auctoritate Pauli Pp. VI Promulgatum. Ordo Benedicendi Oleum Catechumenorum et Infirmorum et Conficiendi Chrisma, editio typica (Vatican City: Typis Polyglottis Vaticanis, 1971). Hereafter, the Ordo.

${ }^{40}$ All translations are mine unless otherwise noted. The English translation currently in use ritually was copyrighted by ICEL (International Committee on English in the Liturgy) in 1972 and is available in the 1975/1985 Sacramentary: Roman Missal Revised by Decree of the Second Vatican Council and Published by Authority of Pope Paul VI. The Sacramentary. Appendix II: Rites of the Blessing of Oils and Consecrating the Chrism (New York: Catholic Book Publishing Co., 1985). The 1972 translation has since been reprinted in the 2012 Roman Pontifical. ICEL's 1972 translation follows the translation principle of dynamic equivalence, which prizes eloquence and prayerful reverence over an exactingly literal translation. A new translation in accordance with the formal equivalence principle required by Liturgiam authenticam has been prepared but, at the time of writing this article, has yet to be approved. Avoiding the fervent debate over best practices in translation for ritual use, I assert only that I provide my own translations for the blessings of the oils and chrism in the hope of drawing attention to theological insights most obvious in the Latin texts. 
The oil (olive, according to the rubrics, although other vegetable oil may be used according to geographical need) is described as the produce of "viridi ligno" or "green wood" (\#20.7).41 Although the wood of the olive tree is indeed green, the word choice is a bit odd. Latin has the words arbor and oliva, which together or separately would denote the tree that produces olive berries. ${ }^{42}$ Lignum (wood), however, has metaphorical resonance both with the cross of Christ (cf. Acts 10:39, "suspendentes in ligno") 43 and with the trees-good and bad-of the Garden of Eden (cf. Gen 2:16-17; 3:11, "ligno paradisi ... ligno ... scientiae boni et mali"), as well as the tree of life in the paradise of heaven (cf. Rev 2:7; 22, "ligno vitae"). That the Holy Spirit is asked to come into the oil produced from the viridi ligno recalls how the Spirit already operates in salvation history, from the creation of the universe through the cross of Christ and into the re-creation of all in heaven.

The blessing further describes the oil as produced by God "ad refectionem corporis," or "for the restoration of the body" (\#20.8). ${ }^{44}$ Here we have a beautiful double entendre left over from the prayer's ancient days. Oil, "fat" or otherwise, does not spring directly from the ground or sprout naturally from trees, instead, oil is made by the work of human hands. ${ }^{45}$ To attribute the making of oil to God rather than to "Farmer Joe," then, highlights something significant about the work of the divine in the human. God made heaven and earth, humans, and olive trees, but God made humans capable of mastering trees in a way that trees cannot master humans. To say that God produced the oil now being blessed for use in the sacrament of the sick nods to the idea that God created humans to partake in the creative and productive act, to care for others in a way akin to God's care for others. Further, the blessing implies that the oil, previous to the Spirit's coming upon it, already functioned for the restoration of the (presumably human) body.

As mentioned previously, ancient peoples used olive oil for medicinal purposes in ways we no longer do, and of course partook of olive oil, as we do now, as part of a restorative repast. It seems, then, that God produced oil from the green wood through human hands specifically for human ailments

41 The 1972 official English translation by ICEL renders this phrase fruit of the earth, probably to echo the eucharistic theme.

42 I am indebted for this insight to Seth Nater Arwo-Doqu, "The Missa Chrismatis: A Liturgical Theology" (PhD diss., The Catholic University of America, 2013), 275ff.

43 All vulgate texts are from the Robert Weber and Roger Gryson, eds., Biblia Sacra Vulgata, 5th ed. (Stuttgart: Deutsche Bibelgesellschaft, 2007).

44 Interestingly, the ICEL's 1972 translation skips this phrase altogether.

45 Caroline Walker Bynum has a fascinating study of divine productions of oil from the bodies of saints or from their tombs in Holy Feast and Holy Fast: The Religious Significance of Food to Medieval Women (Berkeley: University of California Press, 1987). 
and hunger. The second meaning of the phrase bears on understanding viridi ligno in its biblical sense and corporis in its Pauline sense. ${ }^{46}$ This oil, which God has produced through the work of human hands from the green wood of Eden, of the cross, and of paradise, is for the restoration of the whole human person. Although the English word restoration has thus far adequately captured the healing and nurturing aspect of oil, it is worth noting that refectio is literally $r e+f a c i o$, or re-making. Oil derived from olive trees was always intended for use in the re-making, the re-creation of the human person, even before the Spirit has been officially invited into its fatness.

\section{ii. Description of the Spirit}

The Spirit's title, Paraclete or Consoler (as rendered by ICEL), parallels the appellation given to God the Father (totius consolationis Pater) and answers the deep worry of the sick: that no one knows (or cares) what they suffer (\#20.5). With obvious reference to the Johannine understanding of the Holy Spirit as teacher, advocate, and consoler, the blessing of the oil of the sick asks for the Spirit to come into the oil as the person of the Trinity who is experienced most intimately in sickness and in health. Metaphorically or physically lonely and in pain, perhaps in the dark and cold, colloquially the sick are said to be in "low spirits." When the sick are recalled to their community, feeling hopeful, happy, and loved, they are said to be in "high spirits." It is the Holy Spirit who teaches the sick they are not alone, advocates for them before the community, and consoles them in their woes. 47

\section{iii. Movement of the Spirit in the Oil}

Although the preblessed oil already does a great deal for the restoration of the body, the request for the Holy Spirit to come upon it broadens the use of the oil beyond just the restoration of the body to be a "tutamen corporis, animae ac spiritus, ad evacuandos omnes dolores, omnes infirmitates, omnemque aegritudinem" (\#20.11-13). ${ }^{48}$

There can be no doubt, the oil of the sick is an ointment for the whole human person-body, soul, and spirit. This particular oil, moreover, is not

${ }^{46}$ Cf. Adam G. Cooper, Life in the Flesh: An Anti-Gnostic Spiritual Philosophy (Oxford and New York: Oxford University Press, 2008), 39-45.

${ }^{47} \mathrm{Cf}$. International Commission on English in the Liturgy, Rite of Anointing and Pastoral Care of the Sick, in vol. I (769-908) of The Rites of the Catholic Church as Revised by the Second Vatican Ecumenical Council and Published by Authority of Pope Paul VI (New York: Pueblo Publishing, 1990), 6.

48 "A protector/guardian of body, soul and spirit, to eliminate all pain, all infirmity, and all sorrow." 
considered merely a medicine for healing (as ordinary olive oil might be), but a guardian or protector from the various evils that beset the human person plagued by sickness. The Spirit comes into the fatness of the oil so that everyone (omni) who is anointed with the oil of the sick is protected by it (\#20.9), just as the mark of God protected Cain and his descendants and the mark of Christ protects the elect (Gen 4:15, Apoc 7:3). The "parts" of the human person each correspond to the different kinds of sickness they suffer and so are guarded from: the body is guarded from physical pain, the soul from infirmity of purpose, the spirit from sorrow.

The Holy Spirit moves in the oil of the sick to console and protect those anointed by it. It is important to note that the primary role of oil before the blessing, in salvation history generally, is for the salvation of human beings. After the blessing, that role is multiplied and specified: the oil of the sick is bestowed upon those (already baptized Christians) who intentionally seek God and-hindered by some physical or spiritual pain, and with pain the two are often tied-desire the sacrament to show them the way toward salvation. The physical sign of the oil, intended from creation to bring humankind into God, anoints individuals to guard them against each kind of sickness so that they can continue their journey toward God, accompanied by the community of the church.

\section{Blessing of the Oil of Catechumens}

\section{i. Description of the Oil}

The text of this prayer is, in the words of Anthony Ward, "substantially a new and largely free composition." 49 Previous renditions of the blessing of the oil of catechumens included rites of exorcism and adulation, but these "ha [ve] been done away with by the new rite." ${ }^{\circ 0}$ As with the oil of the sick, this blessing speaks to the import of the oil before it has been blessed. The prayer opens, "Deus ... qui signum roboris in olei creatura posuisti," or, "God, [you] who have written a sign of strength in this creature oil" (\#22.1-2). This strength (roboris) is the strength of an oak tree. In his dissertation on the Chrism Mass, Seth Arwo-Doqu writes, "In liturgical texts, the use of robur-roboris denotes the gift of God's strength, his Spirit or his grace, to accomplish something remarkable in or through someone which, otherwise, might not have been accomplished ordinarily on human initiative alone." ${ }^{11}$ Oil, then, has a sign of strength already within it representing God's grace

\footnotetext{
49 Ward, "Sources of the Postconciliar Blessings of the Holy Oils and the Chrism," 207.

50 Arwo-Doqu, "The Missa Chrismatis," 290.

51 Ibid., 291.
} 
to accomplish the extraordinary before the Spirit has been conferred upon it. That the oil is referred to as "creatura" is not unique to the blessing of the oil of catechumens at the Chrism Mass (\#22.2). Many blessings refer to inanimate things as God's creatures, a move that immediately reflects upon God as the Creator. By joining the idea of giving a sign of strength with the creatureliness of the oil, the prayer indicates the intentionality of all creation. The Creator, who created all creatures, has inscribed creation with signs that can be read by those who choose to see them. In this case, the blessing indicates that the sign of strength placed in the oil can be read by those who have not yet formally received the Spirit, which is helpful, considering the oil of catechumens will be received by those who have yet to be baptized.

Once the oil is blessed, God is asked to "concede fortitudinem" to the "catechumenis, qui eo linientur," or to "grant fortitude" to the "catechumens, who are smeared with it" $(\# \mathbf{2 2 . 5}, 4)$.The strength written into ordinary oil was that of the oak tree; the strength of the oil blessed for the catechumens is the strength of a human being-that is, strength of heart and will as well as strength of body.

\section{ii. Description of the Spirit}

The blessing of the oil of the catechumens is the only prayer for the holy oils at the Chrism Mass that does not directly name the Holy Spirit. Instead, the prayer focuses on God the Father as the strength (virtus) and protection of his people and on the catechumens, who are about to transition from being God's people (plebs) to God's children in baptism (\#22.1).

There is, I think, a simple explanation for the absence of an invocation of the Holy Spirit. The oil of the catechumens is intended for men and women who have not yet been reborn in the fire of the Holy Spirit at baptism. Of course, wherever one person of the Trinity acts, the other persons are present, and the Spirit can be seen in God the Father's writing a sign of strength into the holy oil of the catechumens.

\section{iii. Movement of the Spirit in the Oil}

The blessing of the oil of catechumens requests God bless the oil so that the catechumens smeared with it, "divinam sapientiam et virtutem accipientes, Evangelium Christi tui altius intellegant" (\#22.6-8). ${ }^{52}$ Several qualities traditionally attributed to the Holy Spirit are highlighted here: wisdom,

52 "Receiving the divine wisdom and strength, they may more deeply understand the Gospel of your Christ." This is rendered as a direct address to God the Father in ICEL's 1972 translation: "Bring them [the catechumens] to a deeper understanding of the gospel." 
understanding, virtue generally, fortitude, piety (in the later petition that the new Christians "digni adoptionis filiorum effecti ... laetentur" [\#22.9-10]),53 and, of course, in the oil itself, for oil is regarded as a mediator of the Spirit.

Although the Spirit moves in the oil of the catechumens, it does so obliquely, allowing the created nature of the oil that it helped inscribe to speak for the strength that God confers upon his people as they begin their journey to him, following the path designed for them and signaled throughout all creation and challenging a Gnostic tendency to ignore the salvific role of creation.

\section{Consecration of the Chrism}

After the blessing of the oil of catechumens, the bishop ritually and silently mixes the balsam or perfume into the oil, ${ }^{54}$ then invites all those gathered to pray that God the Almighty Father will bless and sanctify the unction ${ }^{55}$ just mixed so that all who receive it will be made worthy of divine redemption. ${ }^{56}$ After this invitation, the bishop breathes over the chrism, extends his hands, and begins one of the consecratory prayers.

\section{Consecratory Prayer (A)}

\section{i. Description of the Chrism}

Prayer A for the consecration of the Chrism opens with an anamnesis of creation, addressing God as "auctor" or "author" "of all growth" (\#25.A.2).57 In lines 5 to 8, the blessing recalls, "Tu enim in principo terram producere fructifera ligna iussisti, inter quae huius pinguissimi liquoris ministrae olivae nascerentur, quarum fructus sacro chrismati deserviret." ${ }^{58}$ Again, the oil produced from the olive trees is asserted as intended from the creation of the first olive trees (Gen 1:11-12). The "richest liquor" produced by these fruit trees uses the same word of "fatness" to describe the oil as previously explicated. It is born (rather than grown) from ministering olives-that is, olives intended from creation to minister to those who will one day receive the sacred chrism. Olive fruits are described as serving (deserviret) for the sacred chrism, that

\footnotetext{
53 "Having been made worthy of adoption as sons ... they rejoice."

${ }^{54}$ Ordo, 23.

55 The term unction may seem unfashionable, but I wish to distinguish unctio (a mixture of oil and perfume) from oleum (a plain oil) and chrisma (the unction blessed and intended for use as a blessing).

${ }^{56}$ Ordo, 24.

57 "Incrementorum omnium."

58 "In the beginning, you ordered the earth to produce fruit-bearing wood/trees, among which this richest liquor was born, whose fruit serves for the sacred chrism."
} 
is with both intentionality and obedience. This is not to suggest that olives are capable of rational thought, but that they are naturally (perhaps specially?) inclined to God's will because, from creation, they were intended to "minister" to those whom their "richest liquor" would anoint in conscious pursuit of God, the author of all growth.

The blessing then describes how "David ... vultus nostros in oleo exhilarandos esse cantavit," 59 referring to Psalm 104/103, a song in praise of God the Creator that speaks of some of God's nonhuman creatures as his ministers, the fire, for instance (Ps104/103:4), and of God's care for all creation (\#25.A.9-11). Oceans and mountains, springs, beasts of the field, birds of heaven, and of course human beings who are nourished with "bread from the earth, wine to gladden our heats, oil to make our faces gleam (exhilarandam), food to build our strength" are cared for by the Lord (Ps 103/ 104:14-15). ${ }^{60}$ Even "the trees (ligna) of the Lord drink their fill" (Ps 103/ 104:16). The reference recalls God's intentionality, that all he made in creation is for the sustenance and strength of human beings, who are ministered to by nonhuman creatures.

The blessing then recalls the flood that wiped away those people who did not seek the Lord (\#25.A.12-15) and the message of peace on earth brought in an olive branch by the dove (Gen 8:11). The mention of the flood followed by an olive branch is immediately paralleled with baptism followed by anointing with chrism: "in novissimis temporibus ... haec olei unctio vultus nostros iucundos efficit ac serenos" (\#25.A.16-21). ${ }^{61}$ The blessing further associates waterfollowed-by-unction with Moses' anointing of his brother Aaron as a priest (\#25.A.22-24). ${ }^{62}$

So far, the blessing has recounted how olives and olive oil have conferred blessing upon humans; about halfway through the prayer an anamnesis of Jesus' baptism in the Jordan and the bestowal of "amplior honor" (greater honor) upon oil begins (\#25.A.25). ${ }^{63}$ Hearkening back to Psalm 104/103, the blessing addresses the Father, "and you manifestly confirmed him

59 "David ... sang that our faces would be made glad with/in oil" (Cf. Ps. 103/104:15, "exhilaret faciem in oleo" [LXX tradition] and "exhiliarandam faciem oleo" [Hebraic tradition]).

${ }^{60}$ All scriptural passages quoted in English are from the New American Bible.

61 "In the most recent times ... this ointment/unction of oil makes our faces pleasant and serene."

${ }^{62}$ Cf. Exodus 30:22-25, which also gives the "recipe" for chrism: olive oil mixed with "the finest spices ... myrrh ... cinnamon ... fragrant cane ... cassia."

${ }^{63}$ The prayer presumes a bestowal of blessing on all oil forever by the coming of the Holy Spirit upon Jesus after his baptism, just as the baptism itself bestowed blessing on all water forever. 
[Jesus] to be the one anointed with the oil of joyfulness (laetitiae) before his friends, as David the prophet ... had sung." 64 Jesus is given the Greek title Christus (anointed one) at the beginning of this anamnesis, indicating that his anointing as the Son of God supersedes his earthly life, but the further point that he is the one anointed (ungendum, this time a thoroughly Latin word) by the oil of joyfulness (oleo laetitiae) applies to the fulfillment of an earthly prophesy.

Notice, too, the quiet distinction between the blessing conferred upon all oil (oleum) and Jesus's title as the Christ. After the concelebrants join the bishop in extending their right hands toward the chrism, the bishop again addresses the Lord on behalf of the church, asking him to sanctify "the richness of this creature [oil] by your [God's] blessing" ${ }^{\prime 65}$ with the help of the Holy Spirit (discussed following) and Christ, "a cuius sancto nomine chrisma nomen accepit" (\#25.A.36, 41). ${ }^{66}$ Linguistically this is an obvious falsehood; theologically the blessing's assertion is really beautiful. This in the second time the word chrism is used in the prayer (the first was in line 8), and the two complete each other. Line 8 maintains that sacred chrism has been a goal of the ministering olives since the first days of creation, while line 41 reveals that chrism receives its sanctity from Christ, not the other way around. Chrism is a creature, Christ the Creator.

\section{ii. Description of the Spirit}

Of course, it is not Christ who moves in the chrism, but the Holy Spirit. In the anamnesis of Jesus' baptism, the Holy Spirit is recalled as descending in the likeness of a dove, serving as the means of confirming Christ as the one anointed with the oil of joyfulness. The descent of the Spirit after Jesus' baptism, then, is his anointing, and it is the Holy Spirit's action of anointing that gives joy to all previous and subsequent anointing in true anamnetic fashion.

When the concelebrants extend their hands over the chrism, the bishop asks the Lord to sanctify it "et ei Sancti Spiritus immiscere virtutem" (\#25. A.39 ${ }^{67}$ so that, infused with the power of the Spirit and through the cooperation of Father and Son, the chrism can be used to anoint "sacerdotes, reges, prophetas et martyres tuos" (\#25.A.42). ${ }^{68}$ This theme is revisited at the close of

\footnotetext{
64 "Et manifeste visus es comprobare eum oleo laetitiae prae consortiubus suis ungendum David propheta ... cecinerat." Probably also referencing Psalm 45.

65 "Huius creaturae pinguendinem." For a discussion of the terms creaturae and pinguendinem, see section III.i previously.

66 "From [Christ's] holy name comes chrism's name."

${ }_{7}$ "And mingle the power of the Holy Spirit [in the chrism]."

68 "Your [God's] priests, kings, prophets and martyrs."
} 
the prayer, when the Spirit is again associated with baptism and the transformation of ordinary people into the "friends" of Christ.

\section{iii. Movement of the Spirit in the Chrism}

As mentioned at the beginning of this section, the consecration of the chrism is the foundation of all blessings in the church, partially because it is from the chrism itself that all blessings flow. The chrism is bestowed upon those who have already been baptized (that is, reborn) in the water and the Spirit as the "chrisma salutis," or "chrism of salvation" (\#25.A.54). Written into the fattest fatness of olive oil by the Spirit, identified in the descent of the Spirit on Christ, and mingled with the Spirit in its consecration, the chrism is a creature infused with sanctification (\#25.A.46).

It is the chrism that anoints (i.e., sets aside, marks as special) individual human beings as priests, prophets, kings, and martyrs. It is chrism that, after baptism has washed away previous sins, enables individuals to "smell" of the innocent life. Indeed, the spicy-sweet perfume of the sacrament calls to mind the royal and prophetic honors of the Old Testament and of Christ himself. Anointing individual members of the church clothes them "vestimento incorrupti muneris" (25.A.52). ${ }^{69}$ Because of the movement of the Spirit in the chrism, all individuals receive the anointing of priest (like Aaron), prophet (like Moses), and king (like David), and all are drawn ever deeper into the life of God. ${ }^{70}$

\section{Consecratory Prayer (B)}

Although Consecratory Prayer (A) rambled through much of salvation history, Consecratory Prayer (B) is shorter and tighter, focused on the sacrifice of Christ and his gift to the church.

\section{i. Description of the Chrism}

With comparative restraint, the consecration begins, "Deus ... qui sanctificantionis olei mysterium in antiquo foedere adumbrasti, et, ubi venit temporum plentitudo, in dilecto Filio tuo singulariter effulgere voluisti,"71 thus covering creation to Incarnation in one fell swoop (\#25.B.1-6). An interesting difference in this account is the limitation of the "sketch" of the mystery (we

69 "The robe of an incorrupt gift," cf. Revelation 19:13, 6:11.

$7^{70}$ Cf. also Lumen Gentium, \$31. Vatican Council II, Dogmatic Constitution on the Church (Lumen Gentium), November 21, 1964, http://www.vatican.va/archive/hist_councils/ ii_vatican_council/documents/vat-ii_const_19641121_lumen-gentium_en.html.

71 "God ... who sketched the mystery of the sanctification of oil in the old covenant, and, when the fullness of time had come, you wished [it] to shine forth uniquely/specially in your beloved Son." 
should hear echoes of the Greek mysterion) of the sanctification of the oil to the ancient covenant. It is, of course, significant that the authors of the prayer did not use the more familiar term Vetus Testamentum, thus allowing us to imagine God's ancient covenant more broadly than the Scriptures and God's relationship with Israel. Because the prayer does not specify a particular covenantal promise nor refer directly to Scripture, it allows us to see the sanctifying mystery "sketched" in all oil-Jewish or otherwise-as part of its creatureliness. Yet, in the fullness of time, the naturally sketched sanctification of oil shines forth with a singular effulgence in the Son. This introduces a light-oil-water metaphor running through Consecratory Prayer (B). It is the oil that shines (as in the Psalm references discussed previously in Consecratory Prayer [A]), and the Spirit who now fills the church to overflowing (cf. \#25.B.9).

The chrism is also described as the sacred mystery through which the Lord dispenses the wealth of his grace upon his human beings, who are considered his children (cf. \#25.B.12-14). After the concelebrants extend their hands toward the chrism, the bishop begs the Lord in the name of the church, "per tuae gratiae virtutem, haec aromatis et olei commixtio fiat nobis benedictionis + tuae sacramentum" (\#25.B.19-21). ${ }^{72}$ The prayer strongly emphasizes the aroma of the chrism, whose smell fills a room like light and which, anointed by sprinkling, symbolizes a pouring out of the Spirit's gifts (cf. \#25.B.9).

\section{ii. Description of the Spirit}

As mentioned previously, Consecratory Prayer (B) elides metaphors of light, oil, and water to communicate the movements of the Spirit. In this prayer, the Spirit is always being caused to do something. After the Son saved humankind by the paschal sacrament, he "Ecclesiam tuam replevit Spiritu Sancto," presumably to make up for the absence of his earthly body (\#25.B.9).73 The Spirit now fills the church to overflowing, uncontained like the shining of the chrism. But the Spirit is not all effervescence. Children (read: the children of God) reborn by baptism are "Spiritus unctione firmentur" and conformed to God's own anointed one (Christos) (\#25.B.15).74 Those who have been physically sprinkled by the unction metaphysically receive an abundant outpouring of the Holy Spirit's gifts (cf. \#25.B.23). The prayer ends with one of the usual Trinitarian conclusions.

\footnotetext{
72 "Through the power of your grace, may this mixture of spice and oil become the sacrament of your blessing + for us."

73 "Replenished your Church with the Holy Spirit."

74 "Braced by the anointing of the Spirit."
} 


\section{iii. Movement of the Spirit in the Chrism}

The movement of the Spirit in the chrism is, as articulated previously, one of flowing and shining, the movement of oil, water, and light. When anointed, human beings are braced by the Spirit, supported after their baptism so that they may continue to conform to God's Christ-that is, so that in their individual anointings they may be conformed to the Anointed One and enabled to participate in his prophetic, priestly, and kingly roles. The chrism becomes a sacrament of the Lord's blessing, pouring out the gifts of the Holy Spirit upon those it has anointed, so that those anointed by the chrism are drawn ever more readily into the Godhead.

Moreover, the Consecratory Prayer (B) petitions God, "loca vel res, sacris oleis signata, splendore sanctitatis exorna" (\#25.B.24). ${ }^{75}$ All those places and objects anointed by the sacred oil become sacred themselves, including (especially) churches and altars. Hearkening to Exodus 30:26-29, these now-sacred objects render those things and people who touch them sacred, thus writing into various objects and places the splendor of sanctity, allowing the light (the Spirit) to shine out on all who behold it. The mystery of the anointing (unguenti mysterio) perfects the increase of God's church (Ecclesiae tuae perfice augmentum) until she grows to the full measure by which the eternal light of the Trinity shines, that is, until the church makes her way fully into heaven (\#25.B.26-27).

\section{Conclusion: In the Richness}

God the Author wrote the sign of salvation into the richest oil from the first creation of olive trees. The Holy Spirit, moving in that writing illuminates the way to heaven through the chrism of salvation shining on the face of Christ, who hung on a green wood tree. The sign of salvation is there for all to read in the created order, sketched into the fatness of olive oil. The sanctification of that oil as the chrism of salvation, however, occurs within the church, at the Holy Thursday Chrism Mass, where the chrism is consecrated for the use of the saints, that is, of those men and women who consciously seek God in their anointing. ${ }^{76}$ The celebration of the consecration of the chrism and the blessing of the holy oils witnesses to a soteriology that interprets the signs written into creation and harnesses them for the communal salvation of the children of God. In following the Holy Spirit's movements recorded in the prayers of the Chrism Mass, we can see a counter to the neo-Pelagianism and neo-Gnosticism against which Placuit Deo warns.

75 "The places and things, signed by sacred oils, furnish with sacred splendor."

${ }^{76}$ Cf. Lumen Gentium, \$40. 
A people who recognize the movement of the Holy Spirit in creation are unlikely to harbor disdain for the material and contingent world of creation, for they will recognize their own salvation as reliant upon their embodied reception of the Spirit in the fatness of creation. 